\title{
AN ATTEMPT TOWARDS AN ASSESSMENT OF THE CERKNICA POLJE WATER BALANCE
}

\author{
POSKUS OCENE VODNE BILANCE CERKNIŠKEGA POLJA
}

\author{
Gregor KOVAČIČ ${ }^{1}$
}

\begin{abstract}
UDC 556.3(497.4 Cerknica)

Gregor Kovačič: An attempt towards an assessment of the Cerknica Polje water balance

This paper deals with the water balance of the Cerknica Polje. The results of previous investigations are compared with the calculations of inflows to and outflows from the polje made for the hydrological year 1975 (411 days). The calculation of the Cerknica Polje water balance is made on the basis of daily volume variations of Lake Cerknica, calculated using the water level data of the Stržen stream at the Dolenje Jezero gauging station and the digital elevation model of the Cerknica Polje (grid cell size $25 \times 25 \mathrm{~m}$ ). For the hydrological year 1975, total runoff from the Cerknica Polje catchment $\left(475 \mathrm{~km}^{2}\right)$ is estimated at 620 million $\mathrm{m}^{3}$ of water or $17 \mathrm{~m}^{3} / \mathrm{s}$. In the observation year, the strongest lake volume increase in terms of discharge was $135 \mathrm{~m}^{3} / \mathrm{s}$, whereas the strongest lake volume decrease was $60 \mathrm{~m}^{3} / \mathrm{s}$. According to calculations, maximum possible inflow to the Cerknica Polje was $232 \mathrm{~m}^{3} / \mathrm{s}$. In the hydrological year 1975, calculated mean outflow from the Cerknica Polje through ponor caves and ponors at the bottom of the polje was $23.69 \mathrm{~m}^{3} / \mathrm{s}$ and maximum calculated outflow was $91.75 \mathrm{~m}^{3} / \mathrm{s}$.
\end{abstract} Keywords: the Cerknica Polje, karst hydrology, water balance, karstic runoff, Lake Cerknica.

\author{
Izvleček \\ UDK 556.3(497.4 Cerknica) \\ Gregor Kovačič: Poskus ocene vodne bilance Cerkniškega \\ polja
}

V članku je predstavljena vodna bilanca Cerkniškega polja. Rezultati predhodnih raziskav so primerjani $\mathrm{z}$ izračuni dotokov in odtokov s polja v hidrološkem letu 1975 (411 dni). Izračun vodne bilance Cerkniškega polja je narejen na osnovi dnevnih sprememb prostornin Cerkniškega jezera, izračunanih $s$ pomočjo podatkov o vodostajih Stržena na vodomerni postaji Dolenje Jezero in digitalnega modela višin Cerkniškega polja (velikost celic $25 \times 25 \mathrm{~m}$ ). Za preučevano leto je skupen odtok s hidrološkega zaledja Cerkniškega polja $\left(475 \mathrm{~km}^{2}\right)$ ocenjen na 620 milijonov $\mathrm{m}^{3}$ vode oziroma $17 \mathrm{~m}^{3} / \mathrm{s}$. V hidrološkem letu 1975 je največje naraščanje prostornine jezera, preračunano $\mathrm{v}$ pretok, znašalo $135 \mathrm{~m}^{3} / \mathrm{s}$, medtem ko je največje zmanjšanje prostornine jezera znašalo $60 \mathrm{~m}^{3} / \mathrm{s}$. Največji možni dotok na Cerkniško polje je izračunan na $232 \mathrm{~m}^{3} / \mathrm{s}$. V hidrološkem letu 1975 je povprečni odtok s Cerkniškega polja skozi ponorne jame in talne ponore znašal $23,69 \mathrm{~m}^{3} / \mathrm{s}$, izračunani največji pa $91,7 \mathrm{~m}^{3} / \mathrm{s}$

Ključne besede: Cerkniško polje, kraška hidrologija, vodna bilanca, kraški odtok, Cerkniško jezero.

\section{INTRODUCTION}

Without any exaggeration, Lake Cerknica is the most known intermittent karst lake in the world. The emergence and disappearing of the lake has excited scientists interest since ever; Kranjc (1986) lists 189 publications on the topic of Lake Cerknica. Until now, there have been several attempts to calculate the water balance of Lake Cerknica (Jenko 1954, 1965; Gospodarič \& Habič
1979; Kranjc 1986). However, the fact that the ponors at the bottom and the edge of the Cerknica Polje are periodically filled up with water (lake) makes the estimation of inflows to and outflows from the polje almost impossible. In this paper one of the possible approaches to the calculation of the Cerknica Polje water balance is presented.

\footnotetext{
${ }^{1}$ University of Primorska, Faculty of Humanities, Koper, Titov trg 5, SI-6000 Koper, e-mail: gregor.kovacic@fhs.upr.si

Received/Prejeto: 30.9.2009
} 


\section{MATERIALS AND METHODS}

To reduce the effect of change in water storage, hydrologic budgets should be worked out for the hydrological year (Bonacci 1987, 2001). Hence, for the estimation of inflows to and outflows from the Cerknica Polje catchment area the hydrological year 1975 (from 28 August 1974 to 12 October 1975, 411 daily values), defined by analyzing the hydrographs of several karst springs, was selected, because it was the year when, since the beginning of observations in the area, the largest number of gauging stations in the Cerknica Polje catchment area were operational. We analyzed daily discharge and water level values from 10 gauging stations in the hinterland of the Cerknica Polje and in the polje itself, as well as data from one gauging station situated on the Rak stream in the Rakov Škocjan outside the polje (Fig. 2). The observation period 1997-2002 was additionally selected for the calculation of lake surfaces and volumes related to the fluctuations of water level at the Dolenje Jezero gauging station (the Stržen stream). All hydrological data were obtained from the Environmental Agency of the Republic of Slovenia. An examination of the locations of the gauging stations has revealed that the measuring points in the observation year 1975 had been chosen carefully in order to minimize possible measuring errors. Nevertheless, it is the author's opinion that the possibility of errors in the measuring of discharges, especially at high waters, existed.

Defining the water budget of the poljes, especially during flooding, is very difficult, since it is almost impossible to control all water inflows (e.g. temporary springs and estavelles) into the polje and all water outflows through ponors out of the polje (Bonacci 1987). All water balance equations are based on the premise that the difference between water inflow and outflow over a given time period for the hydrologic system of interest must equal the change in water storage in that system. According to Bonacci (1987), the general form of the water budget equation for poljes in karst regions is as follows:

$$
\sum_{i=1}^{3} Q i_{i}-\sum_{i=1}^{3} Q o_{j}=\sum_{k=1}^{2}\left(V_{k} / \Delta t\right)
$$

Where:

$Q i_{1}$ : inflow to the polje from the horizons not belonging to its own topographic catchment;

$Q i_{2}$ : inflow from the polje's own topographic catchment;

$\mathrm{Q} i_{3}$ : inflow from other catchments via hydrotechnical structures;

$Q o_{1}$ : outflow through ponors of various dimensions;
$\mathrm{Qo}_{2}$ : water losses by evapotranspiration from the topographic catchment area of the polje;

$\mathrm{Qo}_{3}$ : outflow through the hydrotechnical structures;

$\Delta V_{1}$ : variation in the volume of surface water in the polje, expressed in $\mathrm{m}^{3}$ in $\Delta \mathrm{t}$;

$\Delta V_{2}$ : changes in the volume of groundwater in the topographic catchment of the polje.

Floods in the polje can be observed by measuring inflow quantities and the fluctuation of the water level in the pre-ponor retention (Bonacci 1987). In practice, it is not easy to control accurately all input and output data from a system, especially in the cases where water is inflowing through numerous permanent and temporary springs and outflowing through numerous ponors as it is the case of the Cerknica Polje.

In defining the water budget of the Cerknica Polje, common problems are encountered regarding the measuring of inflows and outflows, since there are no discharge data available for all of the springs contributing to the total inflow to the Cerknica Polje. Therefore, only partial control of inflows is possible. On the other hand, defining outflow from the polje is even more difficult, since outflows through ponors can only be estimated indirectly. Furthermore, another methodological problem surrounding the calculation of the water balance of the Cerknica Polje (lake) is that the gauging stations Gorenje Jezero and Dolenje Jezero on the Stržen stream lie within the area, where the lake appears. Thus, only water levels are measured at those gauging stations, since the discharges are impossible to measure when the water is spilled out from the riverbed. The exception is the Gorenje Jezero gauging station, where a discharge curve allows calculation of discharges up to the value of $45 \mathrm{~m}^{3} / \mathrm{s}$ or the water level elevation of $549.92 \mathrm{~m}$ asl respectively. The Dolenje Jezero gauging station lies at the lowest elevation ( $545.556 \mathrm{~m}$ asl); therefore, the data gathered from it were used for the calculation of the Cerknica Polje water budget.

With some modifications, an equivalent method as proposed by Bonacci (1987) was used for the calculation of outflow from the Cerknica Polje (see Equation 2). In Equation 2, the $Q i_{3}$ and $Q i_{1}$ terms of Equation 1 were not considered, because such inflows either do not exist or are impossible to measure. The $\mathrm{Qo}_{3}$ term of the same equation was not considered, because there is no such outflow. The $\mathrm{Qo}_{2}$ term of Equation 1 is almost entirely reflected in the measured inflows to the Cerknica Polje. One of the major problems was how to estimate evapotranspiration rate, as the most unreliable parameter of the water balance (Bonaci 2001), from the lake 


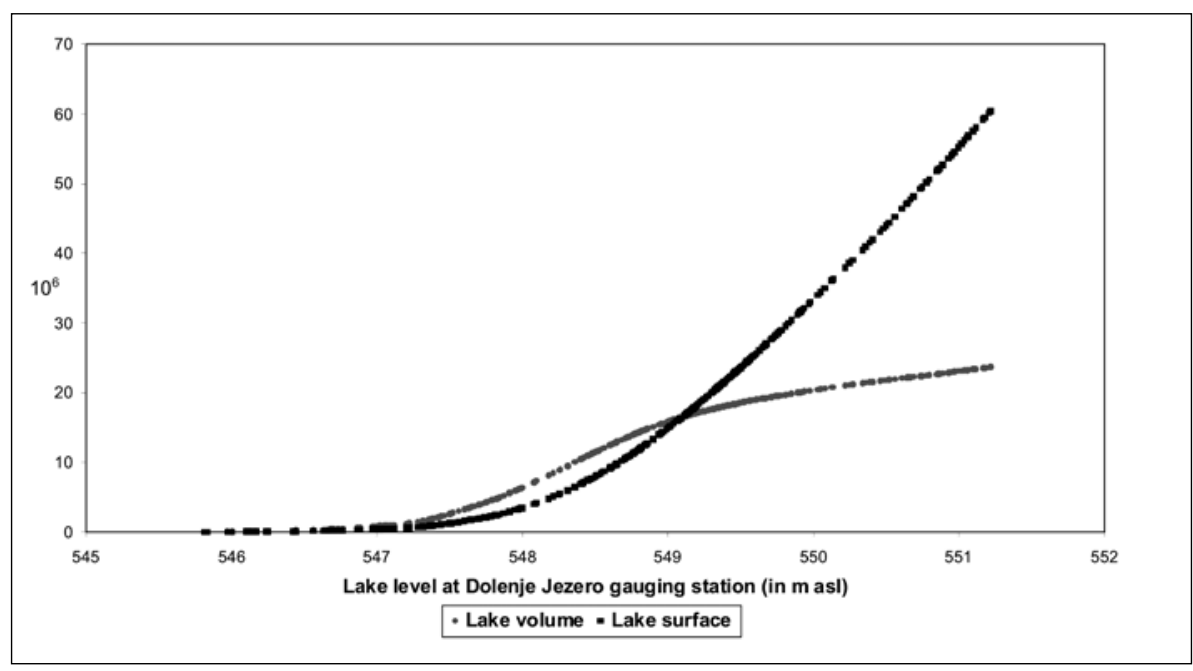

Fig. 1: Variations of Lake Cerknica volume and surface $\left(10^{6} \mathrm{~m}^{2}\right.$ and $\mathrm{m}^{3}$ respectively) in correlation to the water level fluctuations (in meters asl) of the Stržen stream at the Dolenje Jezero gauging station in the hydrological year 1975 (Data source: EARS 2005).

surface on a daily time scale within the $Q o_{2}$ component. As there is no equivalent data for the calculation of evapotranspiration water losses from the lake surface, this was not considered. For the same reason also the precipitation on the lake surface was not considered. The author is of an opinion that introducing these two elements would have led to more unreliable results. The $\Delta V_{2}$ term was not considered, since the measurements of groundwater volume in the topographic catchment of the Cerknica Polje are not performed. On the other hand, for the calculation of water budget for the hydrological year, the $\Delta V_{2}$ term of Equation 1 can easily be eliminated (Bonacci 1987). Equation 2 is identical to the simple water budget equation of poljes presented by Ford and Williams (2007).

$$
Q i-Q o= \pm \Delta V / \Delta t
$$

Where:

$\Delta V / \Delta t$ : variation of lake volume expressed in $\mathrm{m}^{3} / \mathrm{s}$;

$Q i$ inflow to the Cerknica Polje in $\mathrm{m}^{3} / \mathrm{s}$; sum of discharges of the Stržen (Gorenje Jezero; $\mathrm{I}_{2}$ in Fig. 2), Goriški Potok, Žerovniščica, Bloščica, Grahovščica and Martinjščica watercourses ( $\mathrm{I}_{3}$ in Fig. 2) and the Cerkniščica river $\left(\mathrm{I}_{4}\right.$ in Fig. 2); contribution of other karst springs is not included due to the absence of data; precipitation on the lake surface is not included;

Qo: outflow from the Cerknica Polje through ponor caves $\left(\mathrm{O}_{1}\right.$ in Fig. 2) and bottom ponors $\left(\mathrm{O}_{2}\right.$ in Fig. 2); evaporation losses of water from the lake surface are not considered.
The variations of the lake volume were calculated based on water level fluctuations at the Dolenje Jezero gauging station. Firstly, daily water level data of the Stržen stream for the hydrological year 1975 and the period 1997-2002 were converted into elevations (in meters asl). By the computer processing of DEM $25 \times 25 \mathrm{~m}$ (GURS 2005) of the Cerknica Polje area $\left(\mathrm{z}_{\max }=1173 \mathrm{~m}\right.$ asl; $\mathrm{z}_{\text {min }}=543 \mathrm{~m}$ asl), volumes of the lake at selected elevations (water levels) of the Stržen were computed and converted into a function (curve), linking the fluctuations of lake volume to the changes of water level at the Dolenje Jezero gauging station (in meters asl). On the basis of this function (curve), lake volumes for the whole range of existing water level data at the Dolenje Jezero gauging station were calculated. The same approach was used for the calculation of lake surfaces at different water levels of the Stržen. For the calculation of lake surfaces and volumes the Golden Sofware Surfer and ArcGis 9.0 software packages were used. Daily variations of lake volumes allow calculation of daily lake discharges (lake volume increase or decrease) in $\mathrm{m}^{3} / \mathrm{s}$. Based on computed variations of lake volume in a time lag of one day (retention volume) and the sum of available daily discharge data of inflowing watercourses to the polje, approximate calculations of outflow from the Cerknica Polje according to Equation 2 were possible.

The mean annual quantities of corrected precipitation values for 28 precipitation stations situated within the Cerknica Polje catchment were used to calculate the elements of water balance, total runoff and runoff coefficient from the catchment area in the period 1961-1990 (Kolbezen \& Pristov 1998; EARS 2006a). For the hydrological year 1975, measured daily (annual) precipitation values were used. All precipitation point-type data were interpolated to a grid cell size $25 \mathrm{~m}$ using the natural neighbour interpolation algorithm to make a map showing precipitation data in the Cerknica Polje catchment area for selected observation periods. Daily precipitation data were obtained from the Environmental Agency of the Republic of Slovenia. The calculated mean annual values of the real evapotranspiration for the period 1971-2000, published in Water balance of Slovenia 1971-2000 (Frantar 2008), for the whole Slovenian ter- 
ritory were used to estimate and calculate mean annual evapotranspiration as an element of water balance in the Cerknica Polje catchment area. The problem is that neither data on annual evapotranspiration nor daily evapotranspiration time series are available for the individual climatological stations within the Cerknica Polje catchment area. Therefore, modified and corrected evapotranspiration data for the period 1971-2000 were used only for the calculation of total evapotranspiration in the hydrological year 1975 .

\section{HYDROLOGICAL SETTING}

The Cerknica Polje is a relatively flat enclosed karst depression, with a floor area of $70 \mathrm{~km}^{2}$, extending at the elevations between 550 and $547 \mathrm{~m}$ asl. The bottom of the polje is formed in low permeable dolomites, which cover approximately $2 / 3$ of the area. The dolomitic basis of the polje forces groundwater from the hinterland to emerge in karst springs and to cross the polje superficially (Gams 2003). The catchment area of the Cerknica Polje (lake) extends over $475 \mathrm{~km}^{2}$ (Žibrik et al. 1976), of which more than $80 \%$ is karstified. The flat bottom of the polje covers around $38 \mathrm{~km}^{2}$ and its flooding area is $30 \mathrm{~km}^{2}$ at the maximum (Kranjc 1986).

\section{THE CERKNICA POLJE CATCHMENT AREA}

The majority of inflows to the Cerknica Polje originate from its eastern and northeastern parts (Fig. 2). In the area between the Žerovniščica and Goriški Potok watercourses emerge waters from the Bloke plateau, between the settlement Gorenje Jezero and the most southeastern part of the polje emerge waters from the Loško Polje and along the southern and western rims of the polje emerge waters from the Javorniki and Snežnik karst plateaus at several permanent and periodical springs.

The Cerknica Polje is classified as a border polje, owing to the Cerkniščica river, which is actually the only superficial inflow to the polje. Its catchment area extends in dolomites and its river network is well spread. In the reference period 1961-1990, the mean annual discharge of the Cerkniščica was $1.085 \mathrm{~m}^{3} / \mathrm{s}$. The discharges of the Cerkniščica are exceptionally variable, the ratio between minimum, mean and maximum discharge being 1:103:5,820.

The most important watercourse on the Bloke plateau is the Bloščica river, with a mean annual discharge, measured for the period 1972-1975, of $0.42 \mathrm{~m}^{3} / \mathrm{s}$ (Žibrik et al. 1976). The majority of sinking waters from the Bloke plateau emerge in the karst springs of the Žerovniščica and Lipsenjščica (also known as Šteberščica) watercourses and in some other smaller springs at the northeastern rim of the Cerknica Polje, which has been proven also by tracer tests (Novak 1969; Habič 1976; Kogovšek et al. 2008). In the hydrological year 1975, the mean annual discharge of the Žerovniščica was $0.2 \mathrm{~m}^{3} / \mathrm{s}$, whereas maximum discharge can reach around $7.6 \mathrm{~m}^{3} / \mathrm{s}$ (Žibrik et al. 1976). In the period 1972-1975, the mean annual discharge of the Lipsenjščica was $1.3 \mathrm{~m}^{3} / \mathrm{s}$, maximum discharge was more than $16 \mathrm{~m}^{3} / \mathrm{s}$ (Žibrik et al. 1976). The catchment area of the Bločiško Polje (Novak 1969), the Križna jama cave and the area of Podlož with three small springs (the total discharge of the latter being only a few $1 / \mathrm{s}$ ) belong to the waters originating from the Bloke plateau as well (Novak 1990; Kogovšek et al. 2008). The Žerovniščica and Lipsenjščica discharge values include inflows from the Bloke plateau. Therefore, in order to calculate total inflows to the Cerknica Polje from the Bloke plateau it would be more appropriate to use the Žerovniščica and Lipsenjščica discharge values instead of the Bloščica and Žerovniščica discharge values. Since there are no discharge data for the Lipsenjščica for the hydrological year 1975, the author decided to use the sum of the Žerovniščica and Bloščica discharges instead, as data for the period 1972-1975 show that the sum of the Bloščica and the Žerovniščica mean discharges is approximately two times smaller than the Lipsenjščica mean discharge in the same period (Žibrik et al. 1976).

Waters from the Loško Polje (the Obrh stream) emerge in the karst springs Obrh (up to $24 \mathrm{~m}^{3} / \mathrm{s}$ ), Okence, Cemun (up to $24 \mathrm{~m}^{3} / \mathrm{s}$ ), Podpečmi (up to $27 \mathrm{~m}^{3} / \mathrm{s}$ ) and several other small springs (Kranjc 1986) in the southeastern part of the Cerknica Polje. All of the springs merge into the Stržen stream, which is the major inflow to the Cerknica Polje and can reach up to $84 \mathrm{~m}^{3} / \mathrm{s}$ (Kranjc 1986). During exceptionally dry periods, water from the Stržen flows from the direction of Gorenje Jezero towards the Obrh karst spring, where it sinks (Gams 2003). The Goriški Potok stream emerges at the eastern rim of the Cerknica Polje. Its mean discharge is $0.12 \mathrm{~m}^{3} / \mathrm{s}$ and its maximum discharge can reach almost $2 \mathrm{~m}^{3} / \mathrm{s}$ (Žibrik et al. 1976).

The autogenic precipitation waters from the Snežnik and Javorniki high karst plateaus emerge in several karst springs at the southwestern rim of the Cerknica Polje between the settlements Laze and Otok and the ponors 


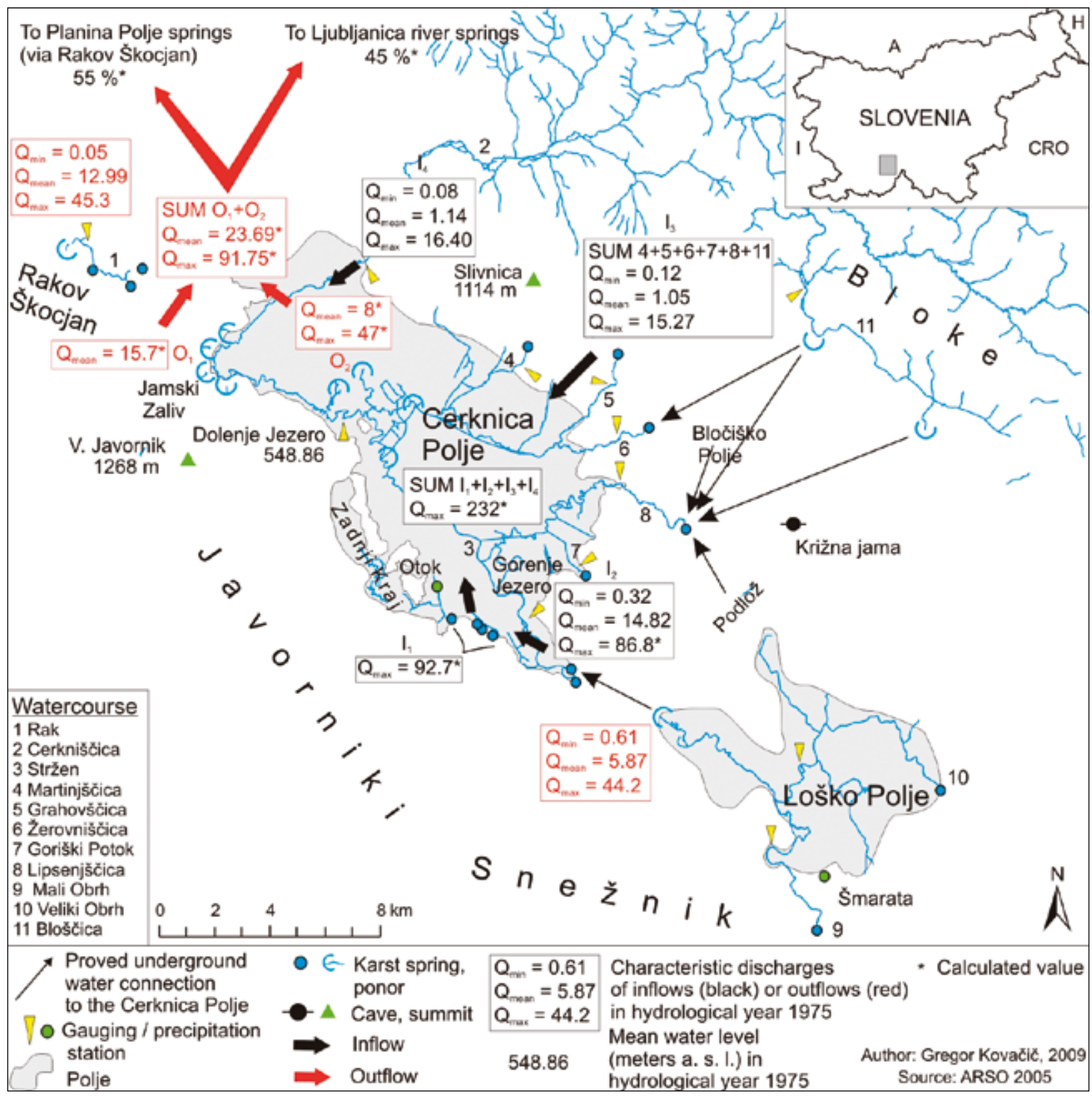

Fig. 2: Map of the Cerknica Polje catchment area with measured or calculated (labelled with *) inflows and outflows in the hydrological year 1975 (Data source: EARS 2005).

in the northwestern part of the polje. The majority of springs at the western rim of the polje are permanent, their total discharge amounting to $35 \mathrm{~m}^{3} / \mathrm{s}$ (Kranjc 1986). It cannot be excluded that waters from the above mentioned plateaus emerge also at the springs Obrh, Cemun, Okence, Podpečmi and other smaller springs in the southeastern part of the polje.

From the dolomitic slopes of Slivnica, some rivulets inflow to the Cerknica Polje; their total discharge can reach around $6 \mathrm{~m}^{3} / \mathrm{s}$ (Kranjc 1986). The Martinjščica $\left(\mathrm{Qmean}=0.14 \mathrm{~m}^{3} / \mathrm{s}\right)$ and the Grahovščica $(\mathrm{Qmean}=$
$0.05 \mathrm{~m}^{3} / \mathrm{s}$ ) are the most important among them (Žibrik et al. 1976).

According to calculations based on the assumption that the runoff from the Cerknica Polje is reflected in the discharges of the Cerkniščica, the Stržen and the Ljubljanica, maximum inflow to the polje was $240 \mathrm{~m}^{3} / \mathrm{s}$ and minimum inflow was around $2 \mathrm{~m}^{3} / \mathrm{s}$ in the period 1948 1952 (Jenko 1965). According to Kranjc (1986), mean annual inflow to the polje for the period 1960-1969 was estimated at $27 \mathrm{~m}^{3} / \mathrm{s}$. Hočevar (1940) as cited by Kranjc (1986) quotes the maximum possible inflow to the Polje 
of $211 \mathrm{~m}^{3} / \mathrm{s}$, of which $32 \mathrm{~m}^{3} / \mathrm{s}(15 \%)$ is attributed to the Cerkniščica, the major karst springs of the Stržen contribute $84 \mathrm{~m}^{3} / \mathrm{s}$ (40\%), other smaller karst springs and surface inflows to the polje contribute around $85 \mathrm{~m}^{3} / \mathrm{s}$ (40\%), the rest is the direct contribution of precipitation falling over the polje $\left(10 \mathrm{~m}^{3} / \mathrm{s}\right.$ or $\left.5 \%\right)$. All these figures are approximations, since it is difficult to identify and measure all the impacts in the complex karst hydrological system of the Cerknica Polje.

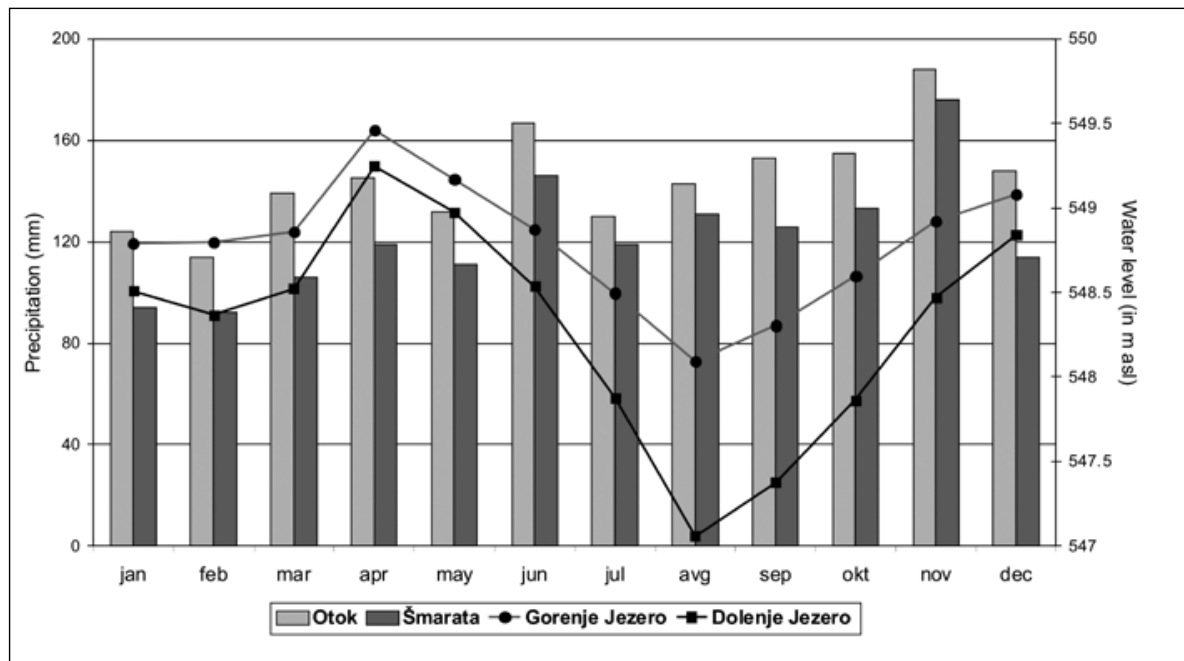

Fig. 3: Mean monthly water levels of the Stržen stream at the gauging stations Gorenje Jezero and Dolenje Jezero for the period 1961-1990 and mean monthly precipitation at the precipitation stations Otok and Šmarata for the period 1961-1990 (Data source: Kolbezen \& Pristov 1998; EARS 2006b).

Lake Cerknica empties through numerous swallow holes at the bottom of the polje and through ponor caves at the northwestern rim of the polje in the area called Jamski Zaliv ("Cave Bay"). The activity of the ponor caves Velika Karlovica, Mala Karlovica, Rakovski Mostek and Svinjska jama as well as of the ponor system of Narti is dependent on lake level fluctuations. The swallow holes at the bottom of the polje are successively emptied in the direction from north to south, in line with the decreasing of the watertable beneath the polje surface (Habič 1974; Gospodarič \& Habič 1979). The swallow holes in the centre of the Cerknica Polje are hydraulically connected with the Ljubljanica river springs (Behrens et al. 1976). In the area called Zadnji Kraj, the lake disappears last and the water table remains in the elevations between 548 and $549 \mathrm{~m}$ asl even at low waters (Habič 1985). Mean annual runoff from the Cerknica
Polje for the period 1960-69 was estimated at $27.2 \mathrm{~m}^{3} / \mathrm{s}$ (Gospodarič \& Habič 1979).

\section{LAKE CERKNICA}

The difference between inflows (211 to $240 \mathrm{~m}^{3} / \mathrm{s}$ ) and outflows ( 40 to $90 \mathrm{~m}^{3} / \mathrm{s}$ ), calculated on the basis of the measurements of the inflow capacity of ponors, results in the inundation of the Cerknica Polje (Jenko 1954; Kranjc 1986). On average, the lake lasts for 8 months and for 2 months there is no lake in the polje. Once in 10 years, the lake does not drain (Kranjc 1986).

The lake is filled with water most often in May, April and December, whereas it is dry most often between August and October (Kranjc 1986). The water from the Stržen riverbed starts to overflow when water level at the Dolenje Jezero gauging station reaches an elevation of $547.4 \mathrm{~m}$ asl (Kolbezen 1998). According to data for the reference period 1961-1990, on average, this elevation was annually exceeded on 286 days, which means that the Cerknica Polje was completely dry only on 79 days in an average year (EARS 2006b). Mean monthly lake levels in the period 1961-1990 show that the greatest extent of the lake is reached in April and December (Fig. 3). The first maximum is a consequence of the snowmelt in the higher positioned parts of its catchment area, which maintains higher lake levels through the whole month. Another reason for the maximum lake levels in April is rain, which, prior to the start of a more active vegetation period contributes to a higher runoff coefficient. The December maximum is a result of the autumnal rain period, reflecting also the effect of karst retention, since the maximum monthly amount of precipitation is recorded in November. The lowest lake levels are recorded in August and the second minimum in February due to snow retention. 


\section{RESULTS AND DISCUSSION}

\section{THE CERKNICA POLJE WATER BUDGET}

Mean annual precipitation in the catchment area of the Cerknica Polje (1961-1990) is estimated at $1787 \mathrm{~mm}$ and mean annual evapotranspiration is $715 \mathrm{~mm}$. Estimated mean annual runoff is $1071 \mathrm{~mm}$ (1961-1990); runoff coefficient is around $60 \%$. Data for the precipitation stations Otok and Šmarata for the same period show the first precipitation maximum in November and the second one in June, while the first precipitation minimum occurs in February and the second one in July. Mean annual precipitation (1961-1990) was 1579 $\mathrm{mm}$ at the Šmarata station and $1805 \mathrm{~mm}$ at the Otok station. In the period 1961-1990, mean annual runoff from the Cerknica Polje catchment area was $16.1 \mathrm{~m}^{3} / \mathrm{s}$, total annual runoff was nearly 509 million $\mathrm{m}^{3}$ and specific runoff was calculated at $34 \mathrm{l} / \mathrm{s} / \mathrm{km}^{2}$. According to the Basic topographic maps 1:5,000, the mean water level of Lake Cerknica is $549 \mathrm{~m}$ asl. Gams (2003) notes that if the water level were exceptionally high at $553.17 \mathrm{~m}$ asl, as was recorded in 1926 using unreliable data (Markošek \& Polajnar 2001), the lake surface could reach over 30 $\mathrm{km}^{2}$. Calculations based on the $25 \mathrm{~m}$ DEM show a slightly smaller extent $\left(28 \mathrm{~km}^{2}\right)$ of the lake at a similar lake level, whereas the lake volume would be slightly above 111 million $\mathrm{m}^{3}$. On 29 November 2000, the highest water level of the Stržen stream at the Dolenje Jezero gauging station in the observation period 1955-2000 was recorded. The lake level was $552.096 \mathrm{~m}$ asl (Markošek \& Polajnar 2001; EARS 2006b) and the lake surface was 26 $\mathrm{km}^{2}$, the volume of water in the lake was slightly above 82 million $\mathrm{m}^{3}$. The level of watertable in the Cerknica Polje varies for approximately $10 \mathrm{~m}$, from 542 to $552 \mathrm{~m}$ asl (Habič 1985).

On the basis of available water level data for the Dolenje Jezero gauging station, the water balance of the Cerknica Polje for the hydrological year 1975 was calculated. In the observation year, the water levels of that gauging station show two distinctive maximums, one at the end of October 1974 and another in midApril 1975 (Fig. 4). The first minimum was recorded in February 1975; the other two minimums were recorded at the beginning and at the end of the hydrological year 1975, in September 1974 and October 1975 respectively. The greatest extent of Lake Cerknica in the observation year at a water elevation of $551.216 \mathrm{~m}$ asl was calculated at $23.7 \mathrm{~m}^{2}$, the water volume was just above 60 million $\mathrm{m}^{3}$. In comparison to the reference period 1961-1990 (286 days or 78.1\%), in the hydrological year 1975 the lake lasted longer, for 347 days in total ( $84.4 \%$ of the year).
Calculated precipitation value for the Cerknica Polje catchment area for the hydrological year 1975 (411 days) is $2124 \mathrm{~mm}$, whereas evapotranspiration is $855 \mathrm{~mm}$. Mean runoff for the same year is calculated at $1268 \mathrm{~mm}$, meaning that total runoff from the Cerknica Polje catchment area is 602 million $\mathrm{m}^{3}$ of water or $17 \mathrm{~m}^{3} / \mathrm{s}$.

\section{THE RECHARGE-DISCHARGE REGIME OF LAKE CERKNICA}

An interesting insight into the dynamics of lake volume variations can be achieved by comparing lake volumes in a time lag of one day. The strongest lake volume increase (or lake discharge) occurs simultaneously with periods of intensive precipitation (Fig. 5), when the discharges of the watercourses flowing to the Cerknica Polje are the greatest as well. In the hydrological year 1975, the lake volume had been increasing for 94 days (27\%), but with different intensity. The greatest lake volume increase was recorded from 19 to 20 March $1975\left(135 \mathrm{~m}^{3} / \mathrm{s}\right)$. At that time, the lake level rose with an intensity of $75 \mathrm{~cm} /$ day $(3.25 \mathrm{~cm} / \mathrm{h})$, as a consequence of an intensive rain event; precipitation of $100 \mathrm{~mm} /$ day was recorded at the Otok precipitation station. In the hydrological year 1975, the most frequent lake volume increase was within the range between 0 and $20 \mathrm{~m}^{3} / \mathrm{s}$ ( $68 \%$ of the days). In the observation year 1975, the emptying of the lake was recorded on 241 days $(69.5 \%)$. The greatest lake volume decrease was recorded from 3 to 4 August 1975 (over $60 \mathrm{~m}^{3} / \mathrm{s}$ ). At that time, the lake level decreased with an average intensity of $31 \mathrm{~cm} /$ day $(1.29 \mathrm{~cm} / \mathrm{h})$. In the observation hydrological year, the most frequent lake volume decrease was within the range between 0 to $10 \mathrm{~m}^{3} / \mathrm{s}$ ( $79 \%$ of the days). The lake level diagram (Fig. 4) shows that the lake volume increase is faster than its decrease.

\section{THE CERKNICA POLJE INFLOW REGIME}

Regardless of the well recognized fact that karst springs in the southeastern part of the Cerknica Polje (the Obrh, the Cemun, etc.) are recharged mainly by sinking waters from the Loško Polje, a comparison between the daily discharges of the Obrh $\left(\mathrm{Q}_{\text {mean }}=5.87 \mathrm{~m}^{3} / \mathrm{s}\right)$ and Stržen streams at the Gorenje Jezero gauging station $\left(\mathrm{Q}_{\text {mean }}=\right.$ $14.82 \mathrm{~m}^{3} / \mathrm{s}$ ) made for the hydrological year 1975 shows a slightly different situation. This proves that the karst springs in the southeastern part of the polje are recharged not only by waters from the Loško Polje, but, to a great extent, by infiltrated precipitation water from the Snežnik and Javorniki karst plateaus. This is indicated by the fact that in the hydrological year 1975 the Stržen 
daily discharges exceeded the Obrh daily discharges by an average of $9 \mathrm{~m}^{3} / \mathrm{s}$. However, this difference can also reach over $42 \mathrm{~m}^{3} / \mathrm{s}$. Analogically, the maximum dis-

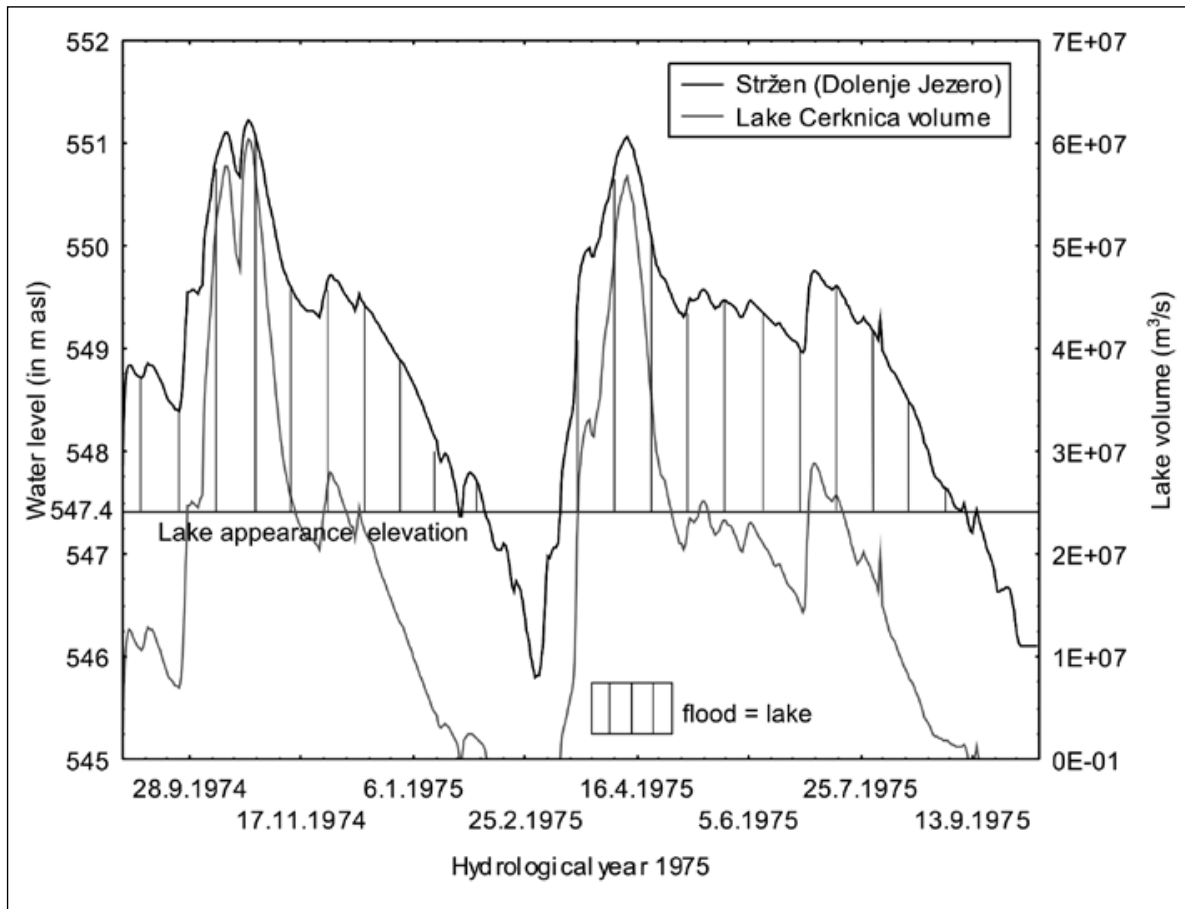

Fig. 4: Water level of the Stržen stream at the Dolenje Jezero gauging station and variations of Lake Cerknica volume in the hydrological year 1975 (Data source: EARS 2005).

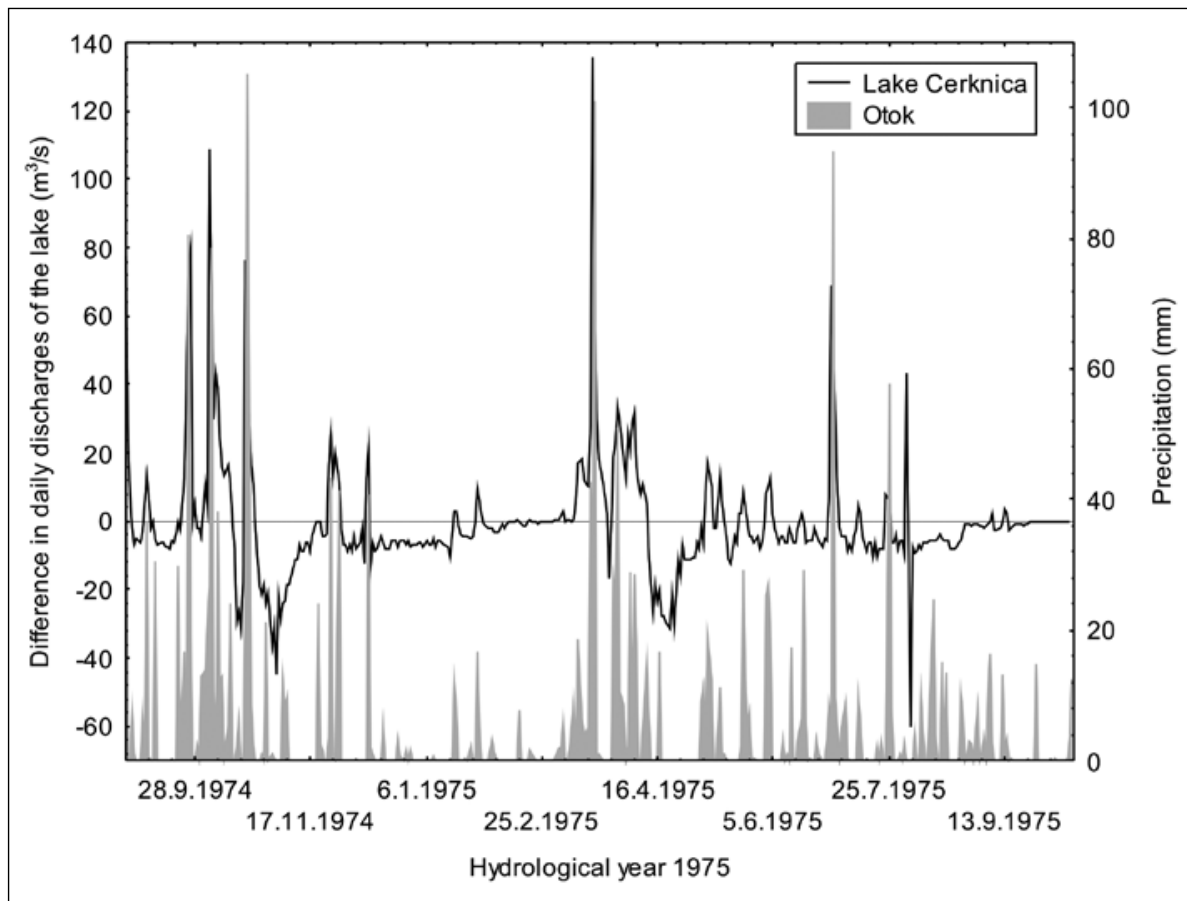

Fig. 5: Daily precipitation at the Otok precipitation station in the hydrological year 1975 and variations of Lake Cerknica volume. Daily lake volume variations are expressed in $\mathrm{m}^{3} / \mathrm{s}$ (Data source: EARS 2006a). charge of the Stržen (Gorenje Jezero) is calculated at $86.8 \mathrm{~m}^{3} / \mathrm{s}$, which is comparable to Kranjc's (1986) approximation $\left(84 \mathrm{~m}^{3} / \mathrm{s}\right)$. In $80 \%$ of the hydrological year 1975 , a greater discharge was recorded for the Stržen (Gorenje Jezero) than it was for the Obrh. On 15 days, the surplus of the Stržen discharge was greater than $40 \mathrm{~m}^{3} / \mathrm{s}$. In $50 \%$ of the observation year, the difference between the daily discharges of the above-mentioned watercourses was within an interval of $\pm 5 \mathrm{~m}^{3} / \mathrm{s}$.

The discharges of the Obrh exceeded those of the Stržen only for $20 \%$ of the observation year (mostly at low waters); in the hydrological year 1975, maximum surplus recorded was $22 \mathrm{~m}^{3} / \mathrm{s}$. The question arises as to where the waters from the Loško Polje flow in such situations. Habič (1976) indicates a possibility of direct groundwater flow through the Javorniki plateau towards karst springs situated in the Planina Polje or/and beneath the Cerknica Polje towards the Ljubljanica river springs; the latter assumption has also been proved by a tracer test (Bidovec 1968). Furthermore, it cannot be excluded that a significant portion of water from the Loško Polje in such conditions emerges in the karst springs at the western rim of the Cerknica Polje westwards from the Gorenje Jezero gauging station. The underground water connection between the Loško Polje and the Cerknica Polje (2 km apart) in all hydrological situations is not as direct as one can assume from the locations of ponors on one side and springs on the other. 
Since the discharge of the Stržen at the Gorenje Jezero gauging station in the major part of the year exceeds that of the Obrh, the discharge values of the ter $(100 \mathrm{~mm} / \mathrm{day}$; the Otok precipitation station) is taken into consideration $\left(20.8 \mathrm{~m}^{3} / \mathrm{s}\right.$ at a lake surface of $18 \mathrm{~km}^{2}$ ), this difference is $92.7 \mathrm{~m}^{3} / \mathrm{s}$ (I1 in Fig. 2). This

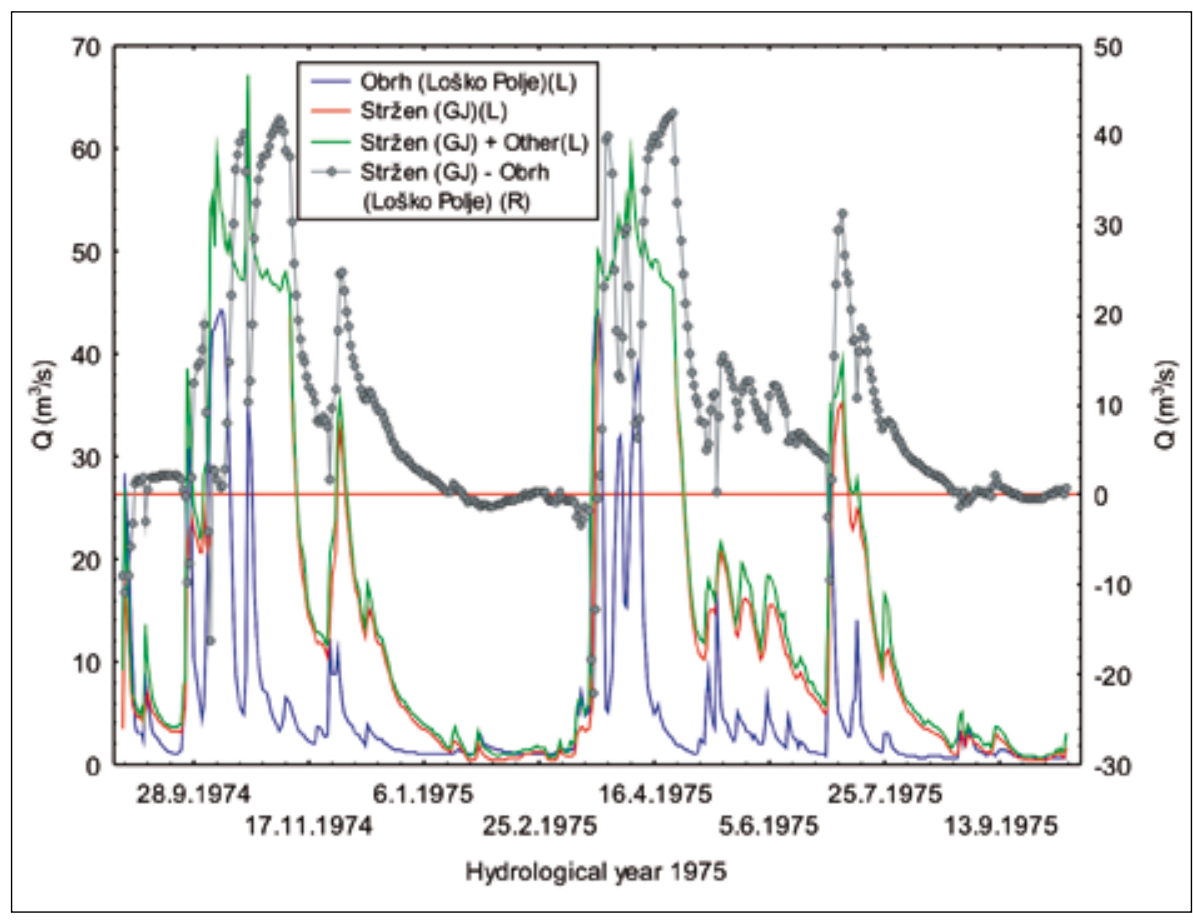

Fig. 6: Inflows to the Cerknica Polje (the Stržen; the Gorenje Jezero gauging station, the Obrh; the Loško Polje and the total of the discharges of the Stržen, Goriški Potok, Žerovniščica, Cerkniščica, Grahovščica, Martinjščica and Bloščica watercourses) in the hydrological year 1975 (Data source: EARS 2005; left y axis). The Stržen discharges are shown only up to a value of $45 \mathrm{~m}^{3} / \mathrm{s}$. Grey dots indicate the difference between the Stržen and Obrh discharges (right y axis). figure reveals that the recharge of the Cerknica Polje from other karst springs and watercourses can be as high as this value; the greatest portion of it is most probably emerging in the karst springs at the foothill of the Javorniki plateau. Considering the maximum possible Stržen discharge at the Gorenje Jezero gauging station $\left(86.8 \mathrm{~m}^{3} / \mathrm{s}\right)$, the maximum discharge of the other contributing inflows to the Cerknica Polje in the hydrological year $1975\left(31.67 \mathrm{~m}^{3} / \mathrm{s}\right)$ and recharge from other sources $\left(113.5 \mathrm{~m}^{3} / \mathrm{s}\right.$, including the direct recharge of the lake by precipitation water), maximum total inflow to the Cerknica Polje is estimated at $232 \mathrm{~m}^{3} / \mathrm{s}$. Jenko (1954) quotes a similar value $\left(240 \mathrm{~m}^{3} / \mathrm{s}\right)$. former were used to calculate total inflows to the Cerknica Polje. It is practically impossible to measure all inflows to the Cerknica Polje because many of them are not permanent. The calculation of inflow (Qi) is therefore made on the assumption that total inflow to the Cerknica Polje is the sum of the Stržen discharges, of the sum of all remaining inflows to the polje (the watercourses Cerkniščica, Martinjščica, Grahovščica, Goriški Potok, Žerovniščica and Bloščica) and of the sum of the inflow from the karst springs at the bottom of the Javorniki karst plateau. For the latter there are no discharge data and they are not included in further calculations. In the hydrological year 1975, the mean discharge of the inflows to the Cerknica Polje was $17.01 \mathrm{~m}^{3} / \mathrm{s}$ (the Stržen and other smaller watercourses); maximum discharge was $67.10 \mathrm{~m}^{3} / \mathrm{s}$ and minimum discharge was $0.66 \mathrm{~m}^{3} / \mathrm{s}$.

On 20 March 1975, the difference between the lake volume increase $\left(135 \mathrm{~m}^{3} / \mathrm{s}\right)$ and total inflow to the Cerknica Polje (the Stržen ( $\mathrm{I}_{2}$ in Fig. 2) and other watercourses $\left(\mathrm{I}_{3}+\mathrm{I}_{4}\right.$ in Fig. 2); $22.39 \mathrm{~m}^{3} / \mathrm{s}$ ) was $113.5 \mathrm{~m}^{3} / \mathrm{s}$. If the direct recharge of the lake by precipitation wa-

\section{THE CERKNICA POLJE OUTFLOW REGIME}

The runoff capacity of ponors from the Cerknica Polje was calculated on the basis of the variation of the retained lake volume during emptying (based on the reduction of the lake level) plus the water entering the lake every day as proposed by Bonacci (1987) and López-Chicano et al. (2002). Calculations in the hydrological year 1975 were possible for those days on which the total discharge of inflowing waters to the Cerknica Polje ( $Q i$; see Equation 2 for explanation) was bigger than the retention volume of the lake $(\Delta V / \Delta t)$. There were 319 such days in that year, meaning that calculations cannot be made only for $8 \%$ of the days with the lake (i.e., when the polje was inundated). In the hydrological year 1975, calculated mean runoff from the Cerknica Polje was $23.69 \mathrm{~m}^{3} / \mathrm{s}\left(\mathrm{O}_{1}+\mathrm{O}_{2}\right.$ in Fig. 2); Gospodarič \& Habič (1979) quote $27.2 \mathrm{~m}^{3} / \mathrm{s}$. On $30 \%$ of the days, the water was outflowing from the polje with an intensity between 0 to $10 \mathrm{~m}^{3} / \mathrm{s}$. In the hydrological year 1975, maximum computed runoff from the polje was $91.75 \mathrm{~m}^{3} / \mathrm{s}$, which is comparable to the estimation of maximum possible runoff (approximately 
$90 \mathrm{~m}^{3} / \mathrm{s}$ ) through ponors from the Cerknica Polje made by Jenko (1954).

Measuring the runoff capacity of the Cerknica Polje ponors is not an easy task. Comparing the discharges of the watercourses in the Ljubljanica river basin, Jenko (1954) as cited by Kranjc (1986) estimated total runoff from the ponor caves of the Cerknica Polje towards the springs of the Planina Polje $\left(74 \mathrm{~m}^{3} / \mathrm{s}\right)$ and via ponors at the bottom of the polje directly towards the Ljubljanica river springs $\left(16.1 \mathrm{~m}^{3} / \mathrm{s}\right)$. Habič (1974) estimates the total runoff capacity of the bottom ponors at around $6 \mathrm{~m}^{3} / \mathrm{s}$. Results for the hydrological year 1975 show that the mean runoff capacity of these ponors can reach around $8 \mathrm{~m}^{3} / \mathrm{s}$ $\left(\mathrm{O}_{2}\right.$ in Fig. 2). The question remains whether this surplus is reflected only in the quantities of water directly recharging the Ljubljanica springs via bottom ponors or can it be, to a certain extent, also attributed to the quantities of water flowing past the Rakov Škocjan hydrological system and inflowing through the springs of the Planina Polje. A rather surprising outcome is the calculation of possible maximum runoff from the bottom ponors of the polje. At the time of maximum calculated runoff from the polje in the observation year $\left(91.75 \mathrm{~m}^{3} / \mathrm{s}\right)$, the discharge of the Rak was $43 \mathrm{~m}^{3} / \mathrm{s}$, which means that around $47 \mathrm{~m}^{3} / \mathrm{s}$ of outflowing water from the polje was flowing past the hydrological system of the Rakov Škocjan. Since these values were measured between 2 and 3 November 1974, the difference cannot be attributed to the effect of strong evaporation from the lake. Furthermore, on 3 August 1975 the difference between the runoff from the polje and the Rak discharge was even greater $\left(60 \mathrm{~m}^{3} / \mathrm{s}\right)$.

Comparing the mean annual discharge of the Rak stream and the calculated discharge from the polje in the hydrological year 1975, the ratio of water flowing directly towards the Ljubljanica river springs (45\%) and the amounts of water flowing through the hydrological system of the Rakov Škocjan (55\%) can be estimated. If only the period when the lake volume was decreasing in the hydrological year 1975 (319 days) is considered, the ratio of waters flowing through the Rakov Škocjan is higher (67\%).

\section{CONCLUSION}

The complex hydrological system of the Cerknica Polje is recharged by superficial watercourses and several karst springs, which also feed the most important watercourse in the polje, the Stržen stream. On the other hand, the runoff from the polje is completely karstic. Some karst springs are directly connected with the ponors of sinking rivers in the hinterland of the polje (the Loško Polje, the Bloke plateau), but are largely also fed by autogenic precipitation water from the Javorniki and Snežnik karst plateaus, as was shown in this study. Both the karstic recharge and the karstic runoff make the assessment of the polje water balance difficult. If it is to some extent possible to measure inflows to the polje, it is almost impossible to measure runoff from the polje, since the water disappears through the ponors at the bottom of the polje and through the ponor caves on its northwestern rim. Due to the appearance of the lake in the polje, measurements are even more difficult.

Some of the results of this study are comparable to those of some previous investigations; some of the calculated figures give a new insight into the dynamics of inflow-runoff regime of the polje. According to data for the hydrological year 1975, maximum inflow to the Cerknica Polje was estimated at $232 \mathrm{~m}^{3} / \mathrm{s}$ and maximum runoff at $91.75 \mathrm{~m}^{3} / \mathrm{s}$. On $68 \%$ of the days on which the lake level increase was recorded in the observation year, the lake volume was increasing with an intensity of between 0 and $20 \mathrm{~m}^{3} / \mathrm{s}$. On $79 \%$ of the days on which the lake level decrease was recorded in the same year, the lake volume was decreasing with an intensity of between 0 and $10 \mathrm{~m}^{3} / \mathrm{s}$. Mean annual runoff in the hydrological year was $23.69 \mathrm{~m}^{3} / \mathrm{s}$. The mean runoff capacity of the ponors at the bottom of the polje was estimated at around $8 \mathrm{~m}^{3} / \mathrm{s}$.

The study gives some new figures and ideas about the inflow-runoff regime of the Cerknica Polje. Yet, some more work in terms of thoroughly planned research still needs to be done in the future in order to get more precise data on the polje water balance. 


\section{REFERENCES}

Behrens, H., Zupan, M. \& M. Zupan, 1976: Tracing with fluorescent tracers.- In: Gospodarič, R. \& P. Habič (eds.) Underground water tracing: Investigations in Slovenia 1972-1975. Institute for Karst Research, pp. 139-164, Postojna.

Bidovec, F., 1968: The investigation of the karst underground water systems and hydrology.- Actes IV CIS, 1965, 3, 279-285.

Bonacci, O., 1987: Karst hydrology: with special reference to the Dinaric karst.- Springer-Verlag, pp. 184, Berlin.

Bonacci, O., 2001: Monthly and annual effective infiltration coefficients in Dinaric karst: example of the Gradole karst spring catchment.- Hydrological Science, 46, 2, 287-299.

Environmental Agency of the Republic of Slovenia (EARS), 2005: Daily discharges and water levels at the gauging stations Slivce (the Rak), Cerknica (the Cerkniščica), Martinjak (the Martinjščica), Grahovo (the Grahovščica), Žerovnica (the Žerovniščica), Goričica (the Goriški Potok), Bloke (the Bloščica), Snežnik (the Mali Obrh), Pudob (the Veliki Obrh), Lipsenj (the Lipsenjščica), Gorenje Jezero (the Stržen) and Dolenje Jezero (the Stržen) for the years 1974, 1975, 1997, 1998, 1999, 2000, 2001 and 2002. The archive of the Environmental Agency of the Republic of Slovenia, Ljubljana.

Environmental Agency of the Republic of Slovenia (EARS), 2006a: Daily precipitation amounts at precipitation stations Babno Polje, Cerknica, Dolenje Jezero, Juršče, Knežak, Leskova Dolina, Mašun, Nova Vas (Bloke), Otok (Lake Cerknica), Planina (Rakek), Poljane (Stari Trg), Postojna, Ravbarkomanda, Razdrto, Ilirska Bistrica, Slavina, Hrib, Zabiče, Gomance, Podgrad, Borovnica, Grčarice, Logatec, Pokojišče, Rakitna, Sodražica, Velika Račna and Šmarata for years 1974, 1975 and reference period 1961-1990. The archive of the Environmental Agency of the Republic of Slovenia, Ljubljana.

Environmental Agency of the Republic of Slovenia (EARS), 2006b: Mean, minimum and maximum monthly discharges and water levels for the period 1961-1990 at the gauging stations Cerknica (the Cerkniščica), Dolenje Jezero (the Stržen) and Gorenje Jezero (the Stržen). The archive of the Environmental Agency of the Republic of Slovenia, Ljubljana.
Ford, D.C. \& P.W. Williams, 2007: Karst hydrogeology and geomorphology.- John Wiley \& Sons, pp. 562, Chichester.

Frantar, P. (ed.), 2008: Water balance of Slovenia 19712000.- Ministry of the environment and spatial planning, Environmental agency of the Republic of Slovenia, pp. 119, Ljubljana.

GURS - Surveying and mapping authority of the Republic of Slovenia, 2005: Digital elevation model $25 x$ 25 m.- Ljubljana.

Gams, I., 2003: Kras v Sloveniji v prostoru in času.Založba ZRC SAZU, pp. 516, Ljubljana.

Gospodarič, R. \& P. Habič, 1979: Kraški pojavi Cerkniškega polja.- Acta carsologica, 8, 7-162.

Habič, P., 1974: Tesnjenje požiralnikov in presihanje Cerkniškega jezera.- Acta carsologica, 6, 35-56.

Habič, P., 1976: Geomorphologic and hydrographic characteristics. Investigations in Ljubljanica river basin, Description of investigated area.- In: Gospodarič, R. \& P. Habič (eds.) Underground water tracing: Investigations in Slovenia 1972-1975.- Institute for Karst Research, pp. 12-27, Postojna.

Habič, P., 1985: Vodna gladina v Notranjskem in Primorskem krasu.- Acta carsologica, 13, 37-78.

Jenko, F., 1954: Vodnogospodarska osnova porečja Ljubljanice. 4. Hidrogeologija. 4-89, Ljubljana.

Jenko, F., 1965: Idejni projekt stalne ojezeritve Cerkniškega jezera.- Zavod za vodno gospodarstvo SRS, pp. 116, Ljubljana.

Kogovšek, J., Prelovšek, M. \& M. Petrič, 2008: Underground water flow between Bloke plateau and Cerknica Polje and hydrologic function of Križna jama, Slovenia.- Acta carsologica, 37, 2-3, 213-225.

Kolbezen, M., 1998: Hidrografija.- In: Vrišer, I. (ed.) Geografija Slovenije. Slovenska matica, pp. 139-172, Ljubljana.

Kolbezen, M. \& J. Pristov, 1998: Surface streams and water balance of Slovenia.- Ministry of the environment and spatial planning, Hidrometeorološki zavod RS, pp. 98, Ljubljana.

Kranjc, A., 1986: Cerkniško jezero in njegove poplave.Geografski zbornik, 25, 73-123.

López-Chicano, M., Calvache, M.L., Martín-Rosales, W. \& J. Gisbert, 2002: Conditioning factors in flooding of karstic poljes - the case of the Zafarraya polje (South Spain).- Catena, 49, 4, 331-352.

Markošek, J. \& J. Polajnar, 2001: Obilne padavine in visoke vode novembra 2000.- Ujma, 14-15, 137-141. 